\title{
Kebijakan fiskal dan upaya mengatasi disparitas ekonomi perspektif Islam
}

\author{
Agus Waluyo \\ Institut Agama Islam Negeri Salatiga (IAIN) Salatiga \\ aagwal@yahoo.com
}

DOI: 10.18326/ijtihad.v17i1.19-38

The purpose of this research is to overcome economic disparity in the perspective of Islamic fiscal. The research findings showed that the effort to overcome economic disparity was conducted through economy development that must refer to the base of Islamic philosophy, namely taubid rubübiyah, keadilan, khalifah and tazkijyah. The primary Islamic fiscal should focuse more on distribution of economy fairly. Fair distribution of economy will guarantee the justice amid community, and there is no difference between the poor and rich people. The principles of justice guarantee primary need to all society. Besides, each of them is able to fulfill their secondary need. In the context of overcoming economic disparity, it can be done through optimizing the receiving from instrument of Islamic fiscal policy through strengthening of regulation, modern and syncron management as well as integration between convensional fiscal and Islamic fiscal policies.

Tulisan ini bertujuan untuk mengatasi disparitas ekonomi perspektif fiskal Islam. Kajian ini menghasilkan temuan bahwa upaya mengatasi disparitas ekonomi perspektif fiskal Islam dilakukan dengan cara pembangunan ekonomi harus memegang teguh dasar-dasar filosofis Islam yaitu taubid rubu>biyah, keadilan, khalifah dan tazkiyah. Concern Fiskal Islam harus lebih difokuskan kepada pendistribusian ekonomi secara merata. Pendistribusian yang merata akan terjamin keadilan di tengah masyarakat, dan juga tidak aka nada jurang pemisah yang tajam antara si kaya dan miskin. Prinsip keadilan menjamin kebutuhan primer secara menyeluruh bagi tiap individu rakyat, di samping masing-masing individu akan mampu memenuhi kebutuhan sekundernya dan luksnya. Dalam konteks upaya mengatasi disparitas ekonomi dapat dilakukan dengan cara optimalisasi penerimaan dari instrumen kebijakan fiskal Islam melalui penguataan regulasi, modernisasi manajemen dan pengelolaan serta sinkronisasi dan integrasi antara kebijakan fiskal konvensional dan fiskal Islam.

Keywords: economy development, disparity, fiscal policy, Islamic fiscal 
ljtihad, Jurnal Wacana Hukum Islam dan Kemanusiaan, Volume 17, No. 1, Juni 2017: 19-38

\section{Pendahuluan}

Pembangunan merupakan proses multidimensi yang melibatkan perubahan-perubahan besar dalam struktur sosial, sikap mental dan kelembagaan, termasuk pula percepatan/akselerasi pertumbuhan ekonomi, pengurangan ketimpangan, dan pemberantasan kemiskinan. Todaro dan Smith (Arsyad, 2010: 11) menjelaskan bahwa keberhasilan pembangunan ekonomi suatu negara ditunjukkan oleh 3 (tiga) nilai pokok, yaitu: (1) berkembangnya kemampuan masyarakat untuk memenuhi kebutuhan pokoknya (sustenance), (2) meningkatnya rasa harga diri (self-esteem) masyarakat sebagai manusia, dan (3) meningkatnya kemampuan masyarakat untuk memilih (freedom from servitude) yang merupakan salah satu hak asasi manusia.

Pemerintah memiliki peran yang sangat penting dalam menggerakkan kegiatan ekonomi agar perekonomian menuju pada kondisi yang diinginkan. Salah satu instrumen yang bisa dimainkan oleh pemerintah untuk mengarahkan kegiatan ekonomi adalah melalui fiskal (Ismail, 2014: 147). Kebijakan fiskal (fiscal policy) merupakan kebijakan pemerintah yang berkaitan dengan pengaturan baik penerimaan pendapatan dari berbagai macam sumber pendapatan seperti pajak maupun pengeluaran pemerintah serta mobilisasi sumber daya dengan tujuan stabilitas ekonomi dan kesejahteraan rakyat. Penerimaan dari negara bersumber dari pajak, penerimaan bukan pajak, dan penerimaan yang berasal pinjaman/ bantuan luar negeri.

Kebijakan fiskal merupakan tindakan pemerintah dalam bidang anggaran belanja negara dengan maksud untuk mempengaruhi jalannya ekonomi. Kebijakan fiskal dapat dibedakan menjadi dua golongan yakni penstabil otomatik (automatic stability policy) dan kebijakan diskresioner (discrecionary fiscal policy). Kebijakan fiskal otomatis merupakan bentuk-bentuk sistem fiskal yang sedang berlaku yang secara otomatis cenderung dapat menimbulkan kestabilan dalam kegiatan ekonomi. Sedangkan, kebijakan fiskal diskresioner atau kebijakan aktif adalah suatu langkah dalam bidang pengeluaran pemerintah dan perpajakan yang secara khusus membuat perubahan dengan tujuan untuk mengatasi masalah-masalah perekonomian yang dihadapi masyarakat (Prasetyo, 2009:182).

Secara umum fungsi kebijakan fiskal adalah fungsi alokasi, distribusi dan stabilisasi perekonomian. Dalam hal alokasi, maka digunakan untuk apa sajakah sumber-sumber keuangan negara, sedangkan distribusi menyangkut bagaimana kebijakan negara mengelola 
pengeluarannya untuk menciptakan mekanisme distribusi ekonomi yang adil di masyarakat, dan stabilisasi adalah bagaimana negara menciptakan perekonomian yang stabil. Kebijakan fiskal dalam sistem ekonomi kapitalis merupakan suatu kebutuhan untuk pemulihan ekonomi (economy recovery) akibat krisis dan menggenjot perekonomian (Rahmawati, 2016: 41).

Dengan demikian kebijakan fiskal merupakan pengelolaan keuangan negara dan terbatas pada sumber-sumber penerimaan serta alokasi pengeluaran negara yang tercantum dalam Anggaran Pendapatan dan Belanja Negara (APBN) (Parcoyo dan Antyo Parcoyo, 2004: 22). Secara teoritis, APBN memiliki 3 (tiga) fungsi pokok yakni stabilisasi, alokasi, dan distribusi. Kemampuan pemerintah mendesain APBN secara baik akan menempatkan ketiga fungsi tersebut secara benar. Kondisi ini menegaskan pentingnya kebijakan fiskal bagi pembangunan suatu negara.

Penyusunan APBN di Indonesia selama ini masih menggunakan sistem konvensional semata. Hal ini terlihat pada beberapa instrumen terkait penerimaan dan pengeluaran negara. Pos-pos peneriman Pemerintah Indonesia meliputi penerimaan pajak, penerimaan negara bukan pajak, dan hibah dan bantuan luar negeri. Penerimaan pajak meliputi: (a) pajak dalam negeri yang terdiri dari pajak penghasilan, perseroan, pertambahan nilai, dan penjualan, dan (b) pajak perdagangan internasional. Adapun penerimaan negara bukan pajak meliputi: (a) penerimaan sumber daya alam, (b) bagian pemerintah atas laba BUMN, (c) penerimaan negara bukan pajak lainnya, dan (d) pendapatan BLU. Adapun pos pengeluarannya meliputi pengeluaran negara yang terdiri dari belanja pusat dan belanja daerah dan pembiayaan yang terdiri dari pembiayaan dalam negeri, pembiayaan luar negeri dan tambahan pembiayaan hutang. Dalam mekanisme operasionalnya, seluruh pemasukan dari berbagai sumber pos penerimaan tersebut dilebur menjadi satu dan seluruhnya digunakan untuk pembiayaan negara.

Bagi masyarakat Indonesia yang mayoritas penduduknya beragama Islam, mekanisme operasional dalam penyunanan APBN tersebut menimbulkan kegelisahan sekaligus tantangan, terutama menyangkut sumber pendapatan negara. Pendapatan pajak dari perusahaan yang dilarang dalam Islam seperti perusahaan minuman keras, tempat-tempat prostitusi, dan hasil dari penjualan barang ilegal/aktivitas ekonomi ilegal merupakan sumber pendapatannya yang tidak serta merta diperbolehkan untuk dipergunakan baik oleh individu maupun umum (publik). Atas kondisi yang demikian perlu upaya pemikiran bersama untuk mencari model 
ljtihad, Jurnal Wacana Hukum Islam dan Kemanusiaan, Volume 17, No. 1, Juni 2017: 19-38

untuk menggabungkan kebijakan fiskal yang telah ada dengan nilai-nilai dan instrumen fiskal dalam Islam demi mewujudkan tujuan-tujuan syariat (al-maqāsid al-syari’ab) yang selanjutnya disebut maqāsid. Kedua model kebijakan dan instrumen fiskal (konvensional dan Islam) memungkinkan untuk dipadukan karena sejak era reformasi telah terjadi upaya dalam pengelolaan APBN dengan menggunakan struktur anggaran berbasis kinerja yang bertujuan meningkatkan kinerja pemerintahan dengan good governance yang menuntut adanya efektifitas, efisiensi, transparan, dan akuntabel dalam pengelolaannya (Jaelani, 2012: 3). Tulisan ini bermaksud menguraikan sebuah tawaran Islam tentang instrumen dan kebijakan fiskal dalam upaya pembangunan ekonomi yang sesuai maqāsid dan mengurangi disparitas pendapatan ekonomi dan distribusi kekayaan.

\section{Kilas balik persoalan disparitas pembangunan ekonomi}

Sebelum dekade 1960an, pembangunan ekonomi didefinisikan sebagai kemampuan ekonomi nasional di mana keadaan ekonominya mula-mula relatif statis selama jangka waktu yang cukup lama untuk dapat menaikkan dan mempertahankan laju pertumbuhan Gross National Product (GNP) hingga mencapai angka 5 sampai 7 persen atau lebih per-tahun. Pengertian ini sangat bersifat ekonomis. Namun demikian, pengertian pembangunan ekonomi mengalami perubahan karena pengalaman pada tahun 1950an dan 1960an yang menunjukkan bahwa pembangunan yang berorientasi pada pertumbuhan GNP semata tidak akan mampu memecahkan permasalahan-permasalahan pembangunan secara mendasar di Negara Sedang Berkembang (NSB). Hal ini tampak pada taraf dan kualitas hidup sebagian besar masyarakat di NSB yang tidak mengalami perbaikan meskipun target pertumbuhan GNP per-tahun telah tercapai. Dengan kata lain, ada tanda-tanda kesalahan besar dalam mengartikan istilah pembangunan ekonomi secara sempit (Arsyad, 2010:11).

Ukuran-ukuran ekonomi tradisional yang sering digunakan selama ini ialah melihat keberhasilan pembangunan dari GNP atau GNP per-kapita. Asumsinya, lewat pertumbuhan akan terjadi "trickle down effect". Ukuran-ukuran ekonomi tradisional tersebut sering menuai kritik karena memiliki banyak kelemahan (Deliarnov, 2015: 273). Ekonomi tradisional atau yang lebih dikenal dengan ekonomi konvensional terpusat bagaimana cara meningkatkan pertumbuhan ekonomi, tetapi sering mengabaikan distribusi pendapatan. Orang yang punya 
pendapatan tinggi semakin tinggi pendapatannya, orang memiliki pendapatan rendah semakin rendah pendapatannya. Selain itu, efek individu, masyarakat maupun negara memacu pertumbuhan dengan meninggalkan etika yang sejatinya perlu dikembangkan dalam pembangunan ekonomi. Hal ini berimbas pada sikap masyarakat yang cenderung tidak memperhatikan tanggung jawab sosial. Kondisi tersebut menyebabkan disparitas ekonomi semakin tinggi.

Dalam perkembangannya, ekonomi konvensional terbukti gagal mempertahankan idealismenya. Kondisi-kondisi ideal yang dijadikan asumsi dalam teori ekonomi konvensional tidak pernah tercapai. Bahkan dalam setengah abad terakhir, ekonomi konvensional semakin menampakkan kelemahannya. Timbulnya kapitalisme memperbesar kesenjangan antar orang kaya dan orang miskin, antara pekerja dan pemilik modal, antara negara maju dan negara berkembang serta menyebabkan tingginya inflasi dan bertambahnya jumlah pengangguran (Syaparuddin, 2010:1). Hasil penelitian The News Economic Foundation (NEF), sebuah lembaga riset yang berkedudukan di Inggris, tentang hubungan antara pertumbuhan pendapatan per kapita dengan proporsi atau share dari pertumbuhan tersebut yang dinikmati oleh kaum miskin, menemukan dan membuktikan bahwa pada dekade 1980an, dari setiap kenaikan 100 \$ AS pendapatan per kapita dunia, maka kaum miskin hanya menikmati 2,2\$ AS atau sekitar 2,2 persen. Artinya 97,8 persen lainnya dinikmati oleh orang kaya. Kemudian pada kurun waktu 1990 hingga 2001, setiap kenaikan pendapatan per-kapita sebesar 100 \$ AS, maka persentase yang dinikmati oleh orang-orang miskin hanya 60 sen saja, atau sekitar 0,6 persen. Sedangkan sisanya, yaitu 99,4 persen, dinikmati oleh kelompok orang kaya. Hal tersebut menunjukkan adanya penurunan share kelompok miskin sebesar 73 persen dan hingga saat ini kesenjangan tersebut semakin menjadi-jadi. Fakta tersebut menunjukkan bahwa perekonomian dunia saat ini cenderung bergerak pada ketidakseimbangan penguasaan aset dan sumber daya ekonomi, yang menjadikan kelompok kaya menjadi semakin kaya dan kelompok miskin semakin miskin. Ironisnya fakta tersebut paralel dengan kenyataan di banyak negara muslim, di mana strategi trickle down effect yang dahulu begitu diagung-agungkan, ternyata hanya menghasilkan kesenjangan sosial yang luar biasa besar (Mannan, 1986:47).

Menurut Kementerian PPN/Bappenas (2014) Gini Coefficient Indonesia pada tahun 2013 mencapai 0,42. Indonesia masih tertinggal dengan negara Amerika serikat, Australia, dan 
ljtihad, Jurnal Wacana Hukum Islam dan Kemanusiaan, Volume 17, No. 1, Juni 2017: 19-38

Jerman yang Gini Coefficient bisa ditekan dibawah angka 0,40. Penyebab kesenjangan ekonomi di antaranya disebabkan oleh: (1) perubahan komposisi kontribusi sektoral terhadap pertumbuhan ekonomi dan lambatnya penurunan kemiskinan, (2) kakunya pasar tenaga kerja formal terutama kebijakan tenaga kerja tentang upah minimum yang disertai berkurangnya kebutuhan tenaga kurang terampil, dan (3) pertumbuhan penduduk kelompok ekonomi menengah ke bawah relative tinggi dan tidak disertai peningkatan upah yang signifikan.

Banyak penyebab dan faktor terjadinya ketidakmerataan distribusi pendapatan di NSB. Menurut Adelman dan Morris (Arsyad, 2010: 284), penyebabnya adalah (1) pertambahan penduduk yang tinggi akan memicu penurunan pendapatan per-kapita, (2) inflasi dimana pendapatan atas uang bertambah namun tidak diikuti secara proporsional oleh pertambahan produksi barang-banrang, (3) ketidakmerataan pembangunan antar daerah, (4) investasi yang sangat banyak dalam proyek-proyek yang padat modal (capital intensive), sehingga persentase pendapatan dari tambahan modal lebih besar dari pada persentase pendapatan yang berasal dari kerja, sehingga angka pengangguran pun bertambah, (5) rendahnya mobilitas sosial, (6) pelaksanaan kebijakan industri substitusi impor yang mengakibatkan kenaikan pada harga-harga hasil industri guna melindungi usaha-usaha golongan kapitalis, (7) memburuknya nilai tukar (term of trade) bagi NSB dalam perdagangan dengan negara-negara maju, sebagai akibat adanya ketidakelastisan permintaan terhadap barang-barang ekspor NSB, dan (8) hancurnya industri-industri kerajinan rakyat seperti pertukangan, industri rumah tangga dan lain-lain.

Pada dasarnya kemiskinan berpangkal pada masalah distribusi kekayaan yang timpang dan tidak adil. Karena itu Islam menekankan pengeturan distribusi ekonomi yang adil agar ketimpangan dalam masyarakat dapat dihilangkan. Firman Allah SWT dalam surat al-Hasyr ayat 7 "supaya harta itu jangan hanya beredar di antara orang-orang kaya saja diantara kamu". Titik tekan ayat tersebut adalah perlunya pengaturan sirkulasi harta agar tidak hanya beredar di lingkungan orang kaya saja.

\section{Instrumen fiskal Islam dalam konteks keindonesiaan}

Islam telah menawarkan instrumen yang sangat beragam untuk optimalisasi proses distribusi income. Tawaran terssebut ada yang menuntut bantuan otoritas dari pemerintah dan ada pula 
yang memang sangat bergantung kepada konsep karikatif personal dan sosial muslim (Zuraidah, 2013: 139-140). Rahmawati (2016: 34) menjelaskan bahwa instrumen yang dimaksud adalah berupa zakat, wakaf, nawā'ib, jizyah, kharaj, khums, 'usyr, kaf-farat, pinjaman, dan amwāl fadla.

Secara lebih detail dapat dijelaskan bahwa struktur APBN dalam sistem fiskal Islam dan instrumennya adalah sebagai berikut. Pertama, pendapatan negara terdiri dari pendapatan tetap seperti zakat, kharaj, jisyah, 'usyr, dan pendapatan tidak tetap terdiri dari khums, infak, shadaqah, wakaf, hibah, kaffarah, warisan kalalah, dan pendapatan halal lainnya. Dengan demikian pendapatan negara ini terdiri dari zakat, wakaf, dan pajak (usyr, kharaj, jizyah dan khums) dan pendapatan lainnya yang bersumber dari pendapatan halal. Kedua, Pengeluaran negara dalam sistem fiskal Islam digunakan untuk penyebaran agama Islam, pendidikan dan kebudayaan dan pengembangan ilmu pengetahuan, pembangunan infrastruktur, pembangunan armada perang dan hankam, dan penyediaan layanan kesejahteraan sosial (Rozalinda, 2016: 209-2010).

Sebagai instrumen pertama dan utama, zakat merupakan inti dari sumber keuangan negara dalam ekonomi Islam. Pendapatan zakat didistribusikan untuk mustahik zakat yang meliputi delapan golongan, sebagaimana yang tercantum dalam QS.. Al- Taubah ((9): 60. Dana yang berasal dari zakat sama sekali tidak diperbolehkan untuk menarik laba atau moda pembangunan. Zakat sebagai sumber penerimaan utama memiliki potensi yang besar mengingat hukumnya yang wajib. Selain itu objek zakat dalam dunia modern saat ini bertambah luas dengan memungkinkannya menarik zakat profesi selain zakat pertanian dan peternakan, zakat perusahaan dan sebagainya. Ajaran Islam dengan rinci telah menentukan syarat, kategori harta yang harus dikeluarkan zakatnya, dan lengkap dengan tarifnya. Pemerintah dapat memperluas objek pajak yang wajib dizakati dengan berpegang pada nas.. umum yang ada dan pemahaman terhadap realita modern. Dalam konteks Indonesia, agar dana zakat secara kuantitatif ataupun kualitatif cukup banyak, maka untuk mengoptimalkannya pemerintah seharusnya lebih serius.

Puskas Baznas (2017) melaporkan perkembangan zakat di Indonesia tumbuh cukup baik, pengumpulan zakat, infak, sedekah nasional Tahun 2015 mencapai 3,6 T dan meningkat signifikan menjadi $5 \mathrm{~T}$ pada tahun 2016 dengan penyaluran dana zakat nasional mencapai 
ljtihad, Jurnal Wacana Hukum Islam dan Kemanusiaan, Volume 17, No. 1, Juni 2017: 19-38

6.806.175 jiwa mustạ̣ik. Angka ini akan terus tumbuh seiring meningkatnya pengetahuan masyarakat terhadap zakat.

Meskipun perkembangan zakat semakin baik, namun jumlah dana yang didapatkan tidak mampu dijadikan sebagai pendapatan utama negara. Tidak seperti pada pemerintahan Islam pada nabi dan al-khulafa' al-rashidun. Zakat dan sedekah saat itu sebagai pendapatan utama negara dan dimanfaatkan untuk kepentingan rakyat. oleh karena itu sudah selayaknya demi mengoptimalkan penerimaan negara.

Instrumen kedua adalah wakaf. Wakaf dari pandangan hukum syara' berarti menahan harta yang mungkin diambil manfaatnya. Menurut Kompilasi Hukum Islam pasal 1, wakaf adalah perbuatan hukum seseorang atau kelompok orang atau badan hukum yang memisahkan sebagian dari benda miliknya dan melembagakannya untuk selama-lamanya guna kepentingan ibadat atau keperluan umum lainnya sesuai dengan ajaran Islam. Sebagai instrumen fiskal maka saat ini mulai berkembang wakaf uang atau tunai. Perkembangan wakaf tunai ini akan semakin mempertegas posisi wakaf sebagai instrument keuangan umat yang sangat potensial.

Instrumen ketiga adalah nawä'ib. Nawa'ib merupakan pajak umum yang dibebankan atas warga negara untuk menanggung kesejahteraan sosial atau kebutuhan dana untuk situasi darurat. Pajak ini dibebankan pada kaum muslim kaya dalam rangka menutupi pengeluaran negara selama masa darurat. Hal ini terjadi dalam masa perang Tabuk. Pajak ini dimasukkan dalam Baitul Mal.

Instrumen keempat adalah jizyah. Jizyah adalah pajak yang dikenakan kepada warga nonMuslim sebagai imbalan untuk jaminan kehidupan yang diberikan oleh warga negara Islam. Pajak ini dimaksudkan sebagai pajak jiwa yang tinggal di wilayah Daulah Islamiyah. Selain pajak jiwa, pajak ini berfungsi sebagai pembayaran kompensasi atas fasillitas sosial-ekonomi, layanan kesejahteraan, serta jaminan keamanan yang mereka terima. Pembayaran jizyah gugur ketika mereka masuk Islam. Bagi orang kafir yang tidak mampu, tidak wajib membayar jizyah karena kefakiran atau kemiskinannya. Pada masa Rasulullah besarnya jizyah adalah 1 dinar per tahun untuk orang dewasa yang mampu membayarnya. Sedangkan ketetapan pada masa Umar adalah 48 Dirham untuk orang kaya yang berpenghasilan tinggi, 24 Dirham untuk yang berpenghasilan menengah dan 12 Dirham untuk orang miskin yang bekerja. 
Konteks Indonesia, konsep jizyah mustahil dilaksanakan mengingat negara kita bukan negara Islam tetapi negara Pancasila. Konsekuensi logisnya, kedudukan antara umat Muslim dan non-Muslim punya kedudukan yang sama, tidak ada yang tersubordinasi meskipun Muslim jadi mayoritas.

Instrumen kelima adalah kharaj. Kharaj merupakan pajak atas tanah yang dimiliki kalangan non-Muslim di wilayah negara Muslim. Tanah yang pemiliknya masuk Islam, maka tanah itu menjadi milik mereka dan dihitung sebagai tanah 'usyr seperti tanah yang dikelola di Madinah dan Yaman. Penentuan besarnya kharaj ditentukan oolleh karakteristik tanah, jenis tanaman, dan jenis irigasi. Perbedaan antara tanah kharajizyah dan 'usyuriyah adalah kalau tanah kharajiyah berarti tanah yang dimiliki hanya kegunaannya, sedangkan lahannya tetap menjadi milik negara. Sementara kalau yang diberikan adalah tanah 'usyuriyah, maka yang dimiliki adalah tanah sekaligus kegunaannya. Kharaj pertama kali diperkenalkan setelah perang Khaibar, ketika itu Rasulullah membolehkan orang-orang Yahudi Khaibar memiliki kembali tanah milik mereka dengan syarat mengeluarkan separuh dari hasil panen tanah tersebut kepada pemerintah Islam sebagai Kharaj (Rozalinda, 2016:215). Penerapan kharaj di Indonesia juga tidak mungkin dilakukan karena dasar munculnya kharaj adalah penaklukan, sedangkan Indonesia didasari oleh konsensus. Seluruh WNI memiliki kedudukan yang sama walaupun terjadi perbedaan ras, suku, dan agama.

Instrumen keenam adalah k.hums. Khums adalah dana yang diperoleh dari seperlima bagian rampasan perang. Khums juga merupakan sistem pajak proporsional, karena ia adalah persentase tertentu dari rampasan perang yang diperoleh tentara Islam sebagai ghanimah setelah memenangkan peperangan. Persentase tertentu dari pendapatan sumberdaya alam, barang tambang, minyak bumi dan barang-barang tambang lainnya juga dikategorikan khums. Di era sekarang khums sulit diwujudkan karena pengenaannya didasarkan pada hasil peperangan. Jika terminologi rampasan diperhatikan kemudian objeknya diperluas maka hasil rampasan kejahatan seperti pencucian uang. Selain objek pengenaan, proporsi pajaknya bisa dimodifikasi agar sesuai.

Instrumen ketujuh adalah 'usyr. Usyr adalah pajak yang dikenakan atas barang-barang dagangan yang masuk negara Islam, atau datang dari negara Islam sendiri. Pajak ini berbentuk bea impor yang dikenakan pada semua pedagang, dibayar sekali dalam setahun dan hanya 
ljtihad, Jurnal Wacana Hukum Islam dan Kemanusiaan, Volume 17, No. 1, Juni 2017: 19-38

berlaku bagi barang yang nilainya lebih dari 200 Dirham. Permulaan 'usyr di negara Islam adalah di masa khalifah dengan landasan penegakan keadilan, karena 'usyr dikenakan pada para pedagang muslim ketika mereka mendatangi daerah asing. Tempat berlangsungnya pemungutan 'usyr adalah pos perbatasan negara Islam, baik pintu masuk maupun pintu keluar sebagaimana bea cukai pada saat ini. Implementasi 'usyr di Indonesia jika didasarkan agama maka susah untuk dillaksanakan. Jika 'usyr didasarkan pada orang asing yang singgah di negara harus membayar pajak maka bisa diimplementasikan dengan catatan harus disesuaikan dengan perkembangan zaman maupun peraturan yang ada.

Instrumen kedelapan adalah kaffarat. Kaffarat merupakan denda yang dulu dikenakan kepada suami istri yang melakukan hubungan di siang hari pada bulan puasa (Ramadhan). Denda tersebut dimasukkan dalam pendapatan negara. Kaffarat dapat diterapkan di Indonesia, perlu regulasi dan perangkat untuk mengatur pembayaran kaffarat tersebut. Walaupun potensi dari instrumen kaffarat tidak besar tetapi akan menambah jumlah penerimaan negara.

Instrumen kesembilan adalah pinjaman. Pinjaman atau utang baik luar negeri maupun luar negeri dalam Islam sifatnya adalah hanya sebagai penerimaan sekunder. Alasannya utamanya adalah bahwa dalam ekonomi Islam tidak mengenal bunga, sehingga pinjaman dalam Islam haruslah bebas bunga. Pengeluaran pemerintah akan dibiayai dari pengumpulan pajak atau bagi hasil. Dalam pengertian ini, Islam tidak melarang untuk melakukan utangpiutang asalkan tidak membebani pengutang, karena sifatnya hanya membantu dan harus segera diselesaikan dalam waktu yang singkat. Sepanjang sejarah pemerintah Islam, negara pernah melakukan utang hanya dua kali, yaitu pada masa kepemimpinan Rasulullah SAW dan kepemimpinan 'Umar ibnu Khattab. Pinjaman-pinjaman yang pernah dilakukan meliputi pinjaman setelah penaklukan kota Makkah untuk pembayaran diyat kaum muslimin kepada Judzaimah atau sebelum pertempuran Hawazin sebesar 30.000 Dirham kepada 'Abdullah Rabi'ah, dan meminjam beberapa pakaian dan hewan-hewan tunggangan dari Sufyan ibn 'Umayyah. Konteks Indonesia, instrumen pinjaman ini bisa menjadi alternatif pembiayaan negara jika memang membutuhkan. Skema pinjaman ini bisa arahkan kepada pinjaman syariah misalnya dengan instrumen sukuk.

Instrumen kesepuluh adalah amwāl fadla. Amwàl fadla merupakan harta benda kaum muslimin yang meninggal tanpa ahli waris, atau berasal dari barang-barang seorang Muslim 
yang meninggalkan negerinya. Penerapan amwäl fadla sangat mungkin dilakukan di Indonesia, potensi kaum muslimin yang meninggal ataupun meninggalkan negara tetap ada. Jika pos ini dikelola dan dibuat regulasinya maka akan menjadi tambahan penerimaan negara.

Mengenai pengeluaran negara selama masa pemerintahan Rasulullah SAW secara sistematis digunakan untuk hal-hal tertentu (Rahmawati: 2016). Untuk memenuhi kebutuhan primer meliputi: (a) biaya pertahanan seperti persenjataan, unta dan persediaan, (b) penyaluran zakat dan ushur kepada yang berhak menerimanya, (c) pembayaran gaji untuk wali, qadly, guru, imam, muadzin dan pejabat negara, (d) pembayaran upah para sukarelawan, dan (e) pembayaran utang negara, serta (f) bantuan untuk musafir (dari daerah fadak). Adapun untuk kebutuhan sekunder meliputi: (a) bantuan untuk orang yang belajar agama di Madinah, (b) jamuan untuk delegasi keagamaan, utusan suku dan negara serta biaya perjalanan, (c) hadiah untuk pemerintahan negara lain, (d) pembebasan kaum muslimin yang menjadi budak, (e) pembayaran denda atas mereka yang terbunuh secara tidak sengaja oleh pasukan kaum muslimin, (f) pembayaran utang orang yang meninggal dalam keadaan miskin, (g) pembayaran tunjangan untuk orang miskin, (h) tunjangan untuk sanak saudara Rasulullah, (i) pengeluaran rumah tangga Rasulullah, dan (j) persediaan darurat.

Dengan adanya kebijakan dan instrumen fiskal diharapkan setiap negara dapat menjalankan kebijakan fiskal yang berdampak pada kesejahteraan kehidupan masyarakat secara maksimum. Dalam Islam konsep kesejahteraan memiliki arti yang luas, meliputi kehidupan di dunia akhirat dan peningkatan spiritual yang lebih ditekankan dari pada kepemilikan material. Hal tersebut yang menjadi pembeda dengan sistem ekonomi sekuler di mana konsep kesejahteraan hidup hanya dibatasi untuk mendapatkan keuntungan maksimum bagi individu di dunia ini. Tidak ada sesuatu apapun yang diberikan kepada masyarakat untuk pemenuhan kebutuhan spritual manusia.

\section{Pembangunan ekonomi dalam bingkai maqāṣid perspektif Islam}

Konsep pembangunan ekonomi konvensional berbeda secara radikal dengan konsep Islam. Kesejahteraan dan falăh yang ingin dicapai dalam kerangka pembangunan ekonomi Islam bukan sekedar untuk memenuhi keperluan duniawi semata-mata, tetapi juga kesejahteraan, kebajikan dan falăḥ di akhirat, dan antara keduanya tidak ada garis pemisah. 
ljtihad, Jurnal Wacana Hukum Islam dan Kemanusiaan, Volume 17, No. 1, Juni 2017: 19-38

Konsep tersebut berarti sebuah proses untuk mengurangi kemiskinan serta menciptakan ketentraman, kenyamanan, dan tata susila dalam kehidupan. Demi tercapainya pembangunan ekonomi yang selaras dengan maqāsid, maka agama dan negara harus seiring dan sejalan untuk memberikan konstribusi positif. Agama dan negara memiliki peran penting dan bertanggung jawab mewujudkan ekonomi yang berkeadilan.

Pembangunan memiliki 3 (tiga) nilai inti, yaitu kecukupan, harga diri, serta kebebasan. Ketiganya merupakan tujuan yang harus dicapai dari suatu pembangunan karena berkaitan secara langsung dengan kebutuhan manusia yang paling mendasar. Bila ditelaah lebih jauh, tiga nilai inti pembangunan tersebut memiliki kemiripan dengan konsep falăḥ sebagai tujuan hidup dalam ekonomi Islam. Perbedaannya adalah konsep falăh mempunyai cakupan yang lebih luas karena tidak hanya menyangkut kehidupan di dunia semata, tetapi lebih dari itu falạ̣̄ menyangkut kebahagiaan hidup di dunia dan akhirat.

Secara umum tujuan pembangunan ekonomi dalam Islam adalah terpenuhinya dan terpeliharanya maqașid (agama, jiwa, akal, keturunan dan harta) sehingga tercapai falaḥ atau kesejahteraan dunia dan akhirat. Ali Rama dan Makhlani (Aprianto, 2016:76) menjelaskan bahwa pembangunan ekonomi merupakan salah satu aspek penting dalam kehidupan yang sangat diperhatikan dalam Islam. Pembangunan ekonomi dimaksudkan untuk menjaga dan melestarikan lima unsur pokok penunjang kehidupan manusia, yaitu agama (din), jiwa (nafs), akal ('aql), keturunan (nasl), dan harta (mal). Selanjutnya, fokus pembangunan ekonomi tidak hanya terletak pada pembangunan material semata, tetapi juga menempatkan manusia sebagai pelaku dan objek utama dari pembangunan itu sendiri seiring fungsinya sebagai khalifah.

Secara konseptual, pembangunan ekonomi dalam Islam bertolak dari pengembangan sumber daya manusia (buman capital) dan penguasaan teknologi sebagai penggerak utama (driving force) pembangunan ekonomi. Pengembangan sumber daya manusia merangkum seluruh potensi, keberdayaan, dan kualitas kemanusiaan dari sudut rohani dan moral. Manusia (buman) sebagai khalifah, diharapkan mampu mengelola alam untuk mencapai kebahagiaan hidup di dunia dan di akhirat dengan akal yang dimilikinya. Manusia sebagai fokus dari pembangunan tidak akan kuat jika tidak terorganisasi dengan baik, maka dibutuhkan faktor yang mendukung perkembangan ini, yaitu solidaritas sosial. Solidaritas sosial sangat membutuhkan suatu kepemimpinan, karenanya kepemimpinan juga menjadi faktor penting lainnya dalam pembangunan Islam. 
Menurut Chapra (1993: 3-9), filosofi pembangunan ekonomi didasarkan pada 3 (tiga) nilai Islam, yaitu tauhid, khiläfah, dan keadilan. Berdasarkan dasar-dasar filosofis tersebut maka prinsip pembangunan ekonomi menurut Islam meliputi 4 (empat) hal. Pertama, pembangunan ekonomi bersifat komprehenshif dan mengandung unsur spiritual, moral dan material yang berorientasi pada tujuan dan nilai. Kebahagian yang ingin dicapai tidak hanya kebahagian dan kesejahteraan material di dunia, tetapi juga di akhirat. Kedua, fokus utama pembangunan adalah manusia dengan lingkungan kulturalnya. Ini berbeda dengan konsep pembangunan ekonomi modern yang menegaskan bahwa wilayah operasi pembangunan adalah lingkungan fisik saja. Islam memperluas wilayah jangkauan obyek pembangunan dari lingkungan fisik kepada manusia. Ketiga, pembangunan ekonomi adalah aktivitas multidimensional sehingga semua usaha harus diarahkan pada keseimbangan berbagai faktor sehingga tidak menimbulkan ketimpangan. Keempat, pembangunan Islam menekankan pada: (a) pemanfaatan sumber daya yang telah diberikan Allah kepada ummat manusia dan lingkungannya semaksimal mungkin; dan (b) pemanfaatan sumber daya melalui pembagian, peningkatannya secara merata berdasarkan prinsip keadilan dan kebenaran. Islam menganjurkan sikap syukur dan adil dan mengutuk sikap kufur dan zalim.

Pembangunan ekonomi menurut ekonomi Islam memiliki dasar-dasar filosofis yang berbeda, yaitu: (1) Taubid Rubübiyah yaitu konsep ini mengajarkan bahwa Allah adalah sang pencipta atas segala sesuatu. Dialah yang menciptakan dunia dan alam. Untuk manusialah yang selanjutnya mengatur model pembangunan yang berdasarkan Islam. (2) Keadilan, yaitu pembangunan yang merata (growth with equity), (3). Khalifah, yang menyatakan bahwa manusia adalah wakil Allah SW'T di muka bumi untuk memakmurkan dan bertanggung jawab atas pengelolaan sumber daya yang diamanahkan kepadanya, dan (4). Tazkiyah, yaitu mensucikan manusia dalam hubungan dengan Allah, sesamanya dan alam lingkungan, masyarakat dan negara (Almizan, 2016: 219). Dasar-dasar filosofis tersebut digunakan sebagai dasar menyusun gagasan dan tindakan dalam pembangunan ekonomi Islam.

\section{Distribusi pendapatan dalam Islam}

Distribusi pendapatan dalam Islam merupakan penyaluran harta yang ada, baik dimiliki oleh pribadi atau umum (publik) kepada pihak yang berhak menerima yang ditujukan untuk 
ljtihad, Jurnal Wacana Hukum Islam dan Kemanusiaan, Volume 17, No. 1, Juni 2017: 19-38

meningkatkan kesejahteraan masyarakat sesuai dengan syariat. Fokus dari distribusi pendapatan dalam islam adalah proses pendistribusiannya. Secara sederhana bisa digambarkan, kewajiban menyisihkan sebagian harta bagi pihak surplus (berkecukupan) diyakini sebagai kommpensasi atas kekayaannya dan di sisi lain merupakan insentif (perangsang) untuk kekayaan pihak defisit (kekurangan) (Rozalinda, 2016: 131). Konsep tersebut secara tersirat dapat dimaknai adanya upaya menekan tingkat disparitas melalui pengaturan distribusi pendapatan dalam konsep ekonomi Islam.

Islam dengan tegas menggariskan kepada penguasa, untuk meminimalisirkan kesenjangan dan ketidakseimbangan distribusi. Pajak diterapkan atas kekayaan seseorang untuk membantu yang miskin dan bentuk dari sistem perpajakan ini berkaitan dengan dengan salah satu prinsip dalam Islam (zakat). Dengan demikian, tidak ada ruang bagi muslim untuk melakukan tindak kekerasan dalam upaya melancarkan proses distribusi pendapatan (Zuraidah, 2013:138). Penurunan disparitas akan dapat memperluas makna dari pembangunan wilayah dan tempatan (Haughton dan Counsell, 2004; Keating, 2005). Hal ini hampir dipastikan dapat membawa ke arah peningkatan kualitas hidup, ikatan sosial dan kesejahteraan yang terpadu atau seimbang.

Dalam perekonomian modern saat ini, tidak dapat dipungkiri bahwa distribusi merupakan sektor terpenting dalam aktivitas ekonomi. Distribusi adalah suatu transfer dari pendapatan dan kekayaan antara individu dengan cara pertukaran atau dengan cara lain, seperti warisan, sadaqah, wakaf, dan zakat (Zarqa, 1995: 181-227). Dalam teori ekonomi mikro Islam, distribusi menempati posisi penting karena pembahasan mengenai hal tersebut tidak hanya berkaitan aspek ekonomi saja, tetapi juga aspek sosial dan politik. Zarqa mengungkapkan bahwa ada beberapa faktor yang menjadi dasar distribusi, yaitu tukar menukar (exchange), kebutuhan (need), kekuasaan (power), sistem sosial dan nilai etika (social system and ethical values) (Sakti, 2007: 144). Zarqa melihat pentingnya memelihara kelancaran distribusi agar tercipta sebuah perekonomian yang dinamis, adil, dan produktif. Dalam Islam penjaminan kelancaran distribusi ini sudah disistemkan melalui prinsip dan ketentuan syariat.

Dalam Islam, distribusi sumber-sumber daya secara adil bertujuan untuk menghilangkan kesenjangan kekayaan dalam masyarakat muslim. Distribusi kekayaan dan pendapatan yang merata dipandang sebagai bagian yang tak terpisahkan dari falsafah nilai Islam dan didasarkan pada komitmen Islam terhadap persaudaraan kemanusiaan. Mengingat bahwa sumber- 
sumber daya relatif terbatas maka maqāsid tidak dapat diwujudkan tanpa digunakan dalam batas kemanusiaan dan kemaslahatan umum. Setiap individu harus berupaya memenuhi kebutuhan pokok secara mandiri. Jika ada yang tidak mampu memenuhi kebutuhan individunya karena cacat atau lainnya maka menjadi kewajiban kolektif untuk membantunya. Selanjutnya pendapatan dan kekayaan tersebut harus didistribusikan secara adil dan merata. Untuk merealisasikan tujuan-tujuan pemenuhan kebutuhan pokok dan mencapai tingkat peluang dan kesempatan kerja maka harus didukung dengan penggunaan sumber-sumber daya yang tersedia secara efisien guna menghasilkan pertumbuhan ekonomi tinggi (Chapra, 1992: 210-213).

Sumber daya harus dimanfaatkan untuk kesejahteraan untuk semua (Chapra, 1992: 207). Karena sifatnya yang relatif terbatas maka sasarannya dapat diwujudkan untuk kemaslahatan umum dalam batas kemanusiaan dengan tetap mempertimbangkan kenyamanan dan menghindari pemborosan. Sumber-sumber daya harus dikelola secara benar dan dipergunakan untuk kepentingan bersama secara adil sehingga dapat mencapai kesejahteraan bagi seluruh umat manusia.

Untuk merealisasikan tujuan-tujuan pemenuhan kebutuhan pokok dan mencapai tingkat peluang wirausaha dana kesempatan kerja yang tinggi harus diiringi dengan penggunaan sumber daya yang tersedia dengan efisien sehingga menghasilkan pertumbuhan ekonomi yang tinggi. Begitu juga sasaran menciptakan distribusi kekayaan yang merata dapat direalisasikan dengan pertumbuhan yang tinggi. Dengan stabilitas ekonomi yang baik akan dapat mereduksi kesulitan hidup dan kesenjangan yang diciptakan oleh resesi, inflasi, dan pergerakan harga yang tidak menentu, serta kurs valuta asing. Oleh karena laju pertumbuhan ekonomi optimal dan minimalisasi ketidakstabilan merupakan hal pokok yang diperlukan untuk memenuhi implikasi khilāafah dan 'adālah.

Aktivitas usaha distribusi dituntut untuk dapat memenuhi hak dan kewajiban yang diinginkan oleh syariat bagi konsumen dan produsen, yaitu pemenuhan kebutuhan masyarakat luas. Kebutuhan utama adalah kebutuhan dasar atau pokok yang harus menjadi prioritas utama untuk dipenuhi dari perekonomian yang dijalankan produsen, konsumen dan distributor. Pemenuhan kebutuhan dasar dan penjaminan kelancarannya dalam perekonomian menjadi faktor penentu kestabilan ekonomi, politik dan sosial dalam kehidupan manusia. 
ljtihad, Jurnal Wacana Hukum Islam dan Kemanusiaan, Volume 17, No. 1, Juni 2017: 19-38

Dalam hal ini peran pemerintah atau negara dalam memastikan kelancaran distribusi ini sangat diperlukan. Negara memiliki banyak pilihan berupa kebijakan melalui regulasi atau perundang-undangan atau instrumen lainnya untuk melakukannya.

Kebijakan yang berpijak pada pertumbuhan ekonomi merupakan kebijakan yang membatasi peredaran harta di kalangan orang kaya saja (Aprianto, 2016: 93). Untuk itulah kebijakan distribusi yang ditawarkan ekonomi Islam sangat bertolak belakang dengan kebijakan ekonomi kapitalis yang berpijak pada metode pertumbuhan ekonomi. Prinsip utama konsep distribusi dalam pandangan Islam adalah peningkatan dan pembagian bagi hasil kekayaan agar sirkulasi kekayaan dapat ditingkatkan sehingga kekayaan yang ada dapat melimpah dengan merata dan tidak hanya beredar diantara golongan tertentu saja. Fiskal Islam menawarkan solusi untuk menekan disparitas ekonomi melalui distribusi kekayaan menurut ekonomi Islam.

\section{Kebijakan fiskal Islam dalam upaya mengurangi disparitas ekonomi}

Menurut Mannan, prinsip Islam tentang kebijakan fiskal dan anggaran belanja bertujuan untuk mengembangkan suatu masyarakat yang didasarkan atas distribusi kekayaan berimbang dengan menempatkan nilai-nilai material dan spiritual pada tingkat yang sama (Mannan, 1997: 230). Lebih lanjut Mannan menjelaskan bahwa dari semua kitab agama masa dahulu, al-Qur'an merupakan satu-satunya kitab yang meletakkan perintah yang tepat tentang kebijakan negara mengenai pengeluaran pendapatan. Dengan demikian kebijakan fiskal dianggap sebagai alat untuk mengatur dan mengawasi prilaku manusia yang dapat dipengaruhi melalui insentif atau meniadakan insentif yang disediakan dengan meningkatkan pemasukan pemerintah.

Kebijakan fiskal merupakan suatu kewajiban negara dan menjadi hak rakyat, sehingga kebijakan fiskal bukanlah semata-mata sebagai suatu kebutuhan untuk perbaikan ekonomi maupun untuk peningkatan kesejahteraan rakyat semata, akan tetapi lebih pada penciptaan mekanisme distribusi yang adil. Hakikat permasalahan ekonomi yang melanda umat manusia saat ini sesungguhnya berasal dari sistem distribusi harta di tengah-tengah masyarakat. Jadi uang publik dipandang sebagai amanah di tangan penguasa dan harus diarahkan terutama pada lapisan masyarakat yang lemah dan orang-orang miskin, sehingga tercipta keamanan 
masyarakat dan kesejahteraan umum (Rahmawati, 2016:29-30).

Prinsip Islam tentang kebijakan fiskal dan anggaran belanja bertujuan untuk mengembangkan suatu masyarakat yang didasarkan atas distribusi kekayaan berimbang dengan menempatkan nilai-nilai material dan spiritual pada tingkat yang sama. Kebijakan fiskal dianggap sebagai alat untuk mengatur dan mengawasi perilaku manusia yang dipengaruhi melalui insentif yang disediakan dengan meningkatkan pemasukan pemerintah. Kebijakan fiskal dalam suatu negara diharapkan sesuai dengan prinsip dan nilai-nilai Islam karena tujuan pokok agama Islam adalah mencapai kesejahteraan umat manusia secara keseluruhan (Rozalinda, 2016:210).

Kebijakan anggaran pemerintah menempati posisi sangat penting dalam mengubah kemiskinan dan kesenjangan ekonomi. Tingginya tingkat kemiskinan dan kesenjangan ekonomi merupakan indikator kegagalan suatu negara dalam proses pembangunan. Karena pembangunan yang dilaksanakan pada prinsipnya ditujukan untuk meningkatkan kesejahteraan masyarakat dan taraf hidup masyarakat. Menurut Baqir As $\}-S\{a d r$, intervensi negara dalam lapangan kehidupan ekonomi sangat diperlukan untuk menjamin keselarasannya dengan norma-norma Islam (Chapra, 2001: 63). Karena itu pemerintah berperan menyediakan berbagai barang publik untuk mendorong pembangunan dan kesejahteraan bersama melalui kebijakan publik dan fiskalnya.

Pembelanjaan pemerintah dalam koridor fiskal Islam berpegang pada terpenuhinya pemuasan semua kebutuhan primer (basic needs) tiap-tiap individu dan kebutuhan sekunder dan luks (al-ḥajat al-kamāliyyah)-nya sesuai kadar kemampuannya sebagai individu yang hidup dalam masyarakat. Menurut Al-Maliky kebutuhan pokok yang disyariatkan oleh Islam terbagi 2 (dua). Pertama, kebutuhan-kebutuhan primer bagi setiap individu secara menyeluruh. Kebutuhan ini meliputi pangan, sandang, dan tempat tinggal. Kedua, kebutuhan-kebutuhan pokok bagi rakyat secara keseluruhan. Kebutuhan-kebutuhan kategori ini adalah keamanan, kesehatan dan pendidikan. Selanjutnya, concern fiskal Islam harus lebih difokuskan kepada pendistribusian ekonomi secara merata. Dengan pendistribusian yang merata akan terjamin keadilan di tengah masyarakat, dan juga tidak aka nada jurang pemisah yang tajam antara si kaya dan miskin. Dengan prinsip keadilan tersebut, akan terjamin kebutuhan primer secara menyeluruh bagi tiap individu rakyat, di samping masing-masing individu akan mampu 
memenuhi kebutuhan sekundernya dan luksnya (Rahmawati, 2016:42).

Dalam Islam, kebutuhan memang menjadi alasan untuk mencapai pendapatan minimum. Sedangkan kecukupan dalam standar hidup yang baik (nisāb) adalah hal yang mendasari dalam sistem distribusi dan redistribusi kekayaan, setelah itu baru dikaitkan dengan kerja dan kepemilikan pribadi. Setiap umat harus mampu mencapai yang minimum terlebih dahulu, bahkan diupayakan agar dapat mencapai standar hidup yang sudah bisa dikatakan baik. Standar kecukupan ini diasumsikan oleh para ulama sebagai titik pembeda dengan yang kekurangan (limit of pittance) (Zuraidah, 2013: 137-138). Islam mengenal batasan tersebut merupakan hak orang yang harus disediakan oleh otoritas sosial dari negaranya. Ini artinya kewajiban menyisihkan sebagian harta bagi 'yang berkecukupan' untuk mereka 'yang kekurangan' adalah merupakan dana kompensasi atas kekayaan mereka. Untuk hal ini, otoritas negara punya kewenangan untuk pengelolaannya.

\section{Penutup}

Kesenjangan ekonomi merupakan suatu fenomena yang amat kompleks, karena tidak saja menyangkut problem kultural, tetapi juga problem struktural yang menyangkut bagaimana negara membuat kebijakan fiskal yang berorientasi pada penanggulangannya. Secara kultural, Islam menganjurkan untuk menumbuhkan peranan setiap individu dalam meningkatkan kualitas hidupnya dan menumbuhkan proses kebersamaan sosial. Secara struktural, Islam meletakkan peran sentral negara dalam menciptakan distribusi pendapatan dan kekayaan masyarakat secara adil dan merata demi menjaga stabilitas dan keberlangsungan perkembangan ekonomi dalam proses kemajuan dan pemerataan serta sebagai fasilitator pemberdayaan masyarakat dalam mencari solusi ke taraf hidup yang lebih layak.

Tujuan pembangunan ekonomi dalam Islam adalah mencapai falāḥ di dunia dan di akhirat, yang berarti kesejahteraan ekonomi di dunia dan keberhasilan hidup di akhirat. Kesejahteraan terkait dengan kepuasan fisik dan kedamaian mental yang hanya dapat dicapai melalui realisasi yang seimbang antara kebutuhan materi dan rohani dari personalitas manusia. Konsep ini mengandung maksud bahwa setiap peningkatan taraf hidup masyarakat itu hendaknya disertai dengan niat atau tujuan untuk mendapat keridaan Allah. Tujuan pembangunan ekonomi dalam Islam adalah mencapai falāḥ di dunia dan di akhirat, yang berarti kesejahteraan ekonomi 
di dunia dan keberhasilan hidup di akhirat. Kesejahteraan terkait dengan kepuasan fisik dan kedamaian mental yang hanya dapat dicapai melalui realisasi yang seimbang antara kebutuhan materi dan rohani dari personalitas manusia. Konsep ini mengandung maksud bahwa setiap peningkatan taraf hidup masyarakat itu hendaknya disertai dengan niat atau tujuan untuk mendapat keridaan Allah.

Upaya mengatasi disparitas ekonomi perspektif fiskal Islam dilakukan dengan cara pembangunan ekonomi harus memegang teguh dasar-dasar filosofis berupa taubid rubübiyah, keadilan, khalifah dan tazkiyah. Di sisi lain, dalam konteks upaya mengatasi disparitas ekonomi dapat dilakukan dengan cara optimalisasi penerimaan dari instrumen kebijakan fiskal Islam seperti zakat, kharaj, jizyah, 'usyr, dan pendapatan tidak tetap terdiri dari khums, infak, shadaqah, wakaf, hibah, kaffarah, warisan, kalälah, dan pendapatan halal lainnya melalui penguataan regulasi, modernisasi manajemen dan pengelolaan serta sinkronisasi dan integrasi antara kebijakan fiskal konvensional dan fiskal Islam.

\section{Daftar pustaka}

Almizan, "Pembangunan Ekonomi dalam Perspektif Ekonomi Islam", dalam Maqdis: Jurnal Kajian Ekonomi Islam, Vol. 1 No. 2 (2016), hlm. 203-222.

Aprianto, Naerul Edwin Kiky. "Kebijakan Distribusi dalam Pembangunan Ekonomi Islam”, dalam Jurnal Hukum Islam, Vol. 14 No. 2 (2016), hlm. 73-96.

Arsyad, Lincolin, Ekonomi Pembangunan, Yogyakarta: UPP STIM YKPN, 2010.

Chapra, M. Umer, Masa Depan Ilmu Ekonomi: Sebuah Tinjauan Islam, Jakarta: Gema Insani Press, 2001.

Chapra, M. Umer, Islam and the Economic Challenge, Herndon: the International Institute of Islamic Thought, 1992.

Chapra, M. Umer, Islam and Economic Development, Islamabad: the International Institute of Islamic Thought, 1993.

Deliarnov, Perkembangan Pemikiran Ekonomi, Jakarta: Rajawali Pers, 2015.

Direktorat Pembinaan Badan Peradilan Agama Direktorat Jenderal Pembinaan Kelembagaan Agama Islam Departemen Agama RI.1991. Kompilasi Hukum Islam.Pasal 1

Haughton, G. dan D. Counsell, Regions, Spatial Strategies and Sustainable Development, London dan Seaford. Routledge and Regional Studies Association, 2004.

Haris, Muh. Islamic Finance and Philantropy: Sharing Experience between Malaysia and Indonesia, Mataram: Sanabil, 2015. 
ljtihad, Jurnal Wacana Hukum Islam dan Kemanusiaan, Volume 17, No. 1, Juni 2017: 19-38

Jaelani, A., "Pengelolaan APBN dan Politik Anggaran di Indonesia dalam Perspektif Ekonomi Islam", dalam Al Qalam: Jurnal Keagamaan dan Kemasyarakatan (ISSN: 14103222), 29(1), (2012), hlm. 1-24.

Mannan, Muhammad Abdul, Teori dan Praktek Ekonomi Islam, terj. M. Nastangin, Yogyakarta: Dana Bhakti Wakaf, 1997.

Mannan, Muhammad Abdul, Islamic Economics: Theory and Practice, Delhi: Idarah-i Adabiyati, 1986.

Parcoyo, Tri Kunawangih, dan Antyo Parcoyo, Aspek Dasar Ekonomi Makro di Indonesia. Jakarta: Cikal Sakti, 2004.

Rahmawati, Lilik, "Sistem Kebijakan Fiskal Modern dan Islam", dalam OECONOMICUS journal of Economicus. Vol.1 No.1 (2016), hlm. 21-48.

Rozalinda, Ekonomi Islam: Teori dan Aplikasinya pada Aktivitas Ekonomi, Jakarta: Raja Grafindo Persada, 2016.

Sakti, Ali, Analisis Teoritis Ekonomi Islam: Jawaban Atas Kekacauan Ekonomi Modern, Jakarta: Paradigma \& Aqsa Publishing, 2007.

Syaparuddin. "Ekonomi Islam: Solusi terhadap Berbagai Permasalahan Sosial-Ekonomi", dalam Jurnal Muqtasid, Vol. 1, No.1 (2010), hlm. 1-18.

Zarqa, Muhammad Anas,"Islamic Distributive Schemes", dalam Readings in Public Finance in Islamic, Jeddah: IRTI, 1995, hlm. 181-227.

Zuraidah, "Penerapan Konsep Moral dan Etika dalam Distribusi Pendapatan Perspektif Ekonomi Islam", dalam Jurnal Hukum Islam, Vol. 8 No.1 (2013), hlm. 137-153. 